\title{
THE EFFECTIVENESS OF USING TEAM GAMES TOURNAMENT IN STUDENTS UNDERSTANDING ON PAST TENSE AT SECONDGRADE OF MTS ROUDHOTUL KHUFFADZ 2016/2017
}

\author{
Doni Sudibyo \\ donisud@unimudasorong.ac.id \\ Nursalim \\ adennursalim@gmail.com \\ Sitti Nur Sa'adah \\ nursaadah@gmail.com
}

\section{Education University of Muhammadiyah Sorong, Indonesia}

\begin{abstract}
This study aimed at knowing wether Team Games Tournament (TGT) is effective in students' understanding on past tense or not. This study had conducted at Mts Roudhotul Khuffadz in second grade that focused on two classes VIIIa (as the control group) and VIIIB (as the experimental group). The sample were fourthy students. The data were collected by using pre test and post test test. The form of the test was essay. After giving the pre-test, then the researcher giving the treatment and the steps in teaching learning proses were ;(1.) the teacher gave the explanation;(2) the teacher devides the students become four groups ;(3) each group discuss the sheetwork that has given by the teacher;(4) each group presentation their worksheet to be the winner ; (5) if the students in each group cannot answer the question or giving the wrong answer, it will be open the opportunity to the others group to answer. After giving the treatment, the researcher gave post test. The researcher was using Quantitative research and quasi experimental as the design. The data were analyzed by using T-test Formula. The result of the study indicate that Team Games Tournament (TGT) was effective to the students in understanding past tense. It shown from the result data, it showed that the result of post-test in experimental class(a class which is using Team Games Tournament "TGT") is higher than control class( a class which is given conventional method ). It can be seen from the mean score where 74,5 is higher than 70,55. The effectiveness of Team Games

Tournament (TGT) is also proved from the result of T-test in which is 2,407 2.021. When was higher than, (Alternative Hypothesis) was

accepted. The researcher conclude that Team Games Tournament (TGT) was effective in students understanding past tense.
\end{abstract}

Key Words : Team Games Tournanament (TGT), Past Tense. 


\section{INTRODUCTION}

Language is used for communication; grammar is one of the long aspect as the language rules which influence four English skills that should be applied in the real communication. Grammar consist of many parts and it should be learnt by the students. One of grammar aspect is tenses. Grammar has fundamental role in English language and tenses is one of the most problems for the students. There are many problems faced in teaching and learning grammar, one of them is about the component of language. The other is the teacher have a problems to teach and design material well for the students. In teaching grammar or tenses, the students are expected to understand. In junior high school the students extended to learn some tenses including simple past tense. Simpel past tense indicates that an activity on situation began and ended at the particular time in past tense.

Grammar is one of basic aspect to teach the students about tense in high level. There were many problems that the researcher found it and one of them is past tense. The students have problems to make the correct sentence, to put verb in the sentence and also to differentiate of the verb form. As we know, in past tense there are the differences between one another tenses for example, in past tense it uses verb2. In other word, there is a verb change for examples "Go" become Went. The students also still confused how to change the verbs in sentences orhowto use or put auxiliaries verb in negative and interrogative sentence.

Some of the students confused to change the verbs in past tense. Although it has same meaning but it has different words for examples in present tense "I Goto Bali this weeks" become "I Went to Bali last weeks" in past tense. It makes the students feel bored in studying English grammar especially fopast tense. According to Huddeston \& Pullum (2005:29) an explanation that verb is a lexical fundamental which do not stay or form changes and meaning.

The purpose of this study is the researcher wants to know the effectiveness of Team Game Tournament (TGT) on students' understanding in changing verbs on past tense. It makes the researcher feels have a challenge to do a research at MTS Roudhotul Khuffadz Aimas. Using different technique in teaching to make the students understand about past tense and able to understand about verb changes. Based on the researcher experience during observation in second grade at MTS Roudhatul Khuffadz Aimas, the researcher found some problems and one of them is about tenses especially on past tense. The students are confused on how to make a good sentence or correct sentence in past tense.

The researcher chose Team GamesTournament (TGT) technique to be applied in teaching learning process and help the students in understanding past tense. Team Games Tournament (TGT) technique is one of kinds of cooperative learning that easier 
to be applied, this game involve all students activities without differentiate them. In teaching using this game could help the students in understanding past tense. In other side, this technique also make the students enjoy, responsible, honest, and cooperative to helps each other to be the winner.

The researcher is interested in investigating whether Team Games Tournament (TGT) could improve students' ability in understanding verb changes on past tense or not. By this technique, the students are expected to be active then adding their vocabulary, their cooperative, then the students can differentiate and understand verb changes on past tense.

\section{LITERATURE REVIEW}

\section{Previous Related Study}

The first research has written by Siti Farida Ridwan. In this study, (2014) entitled the effectiveness of jigsaw technique in teaching simple past tense at second grade of MTS Al-Ikhwan. She wants to find out whether jigsaw technique is effective to improve students' ability in past tense. The sample of her study is consisted of 25 students at second grade of MTS Al-Ikhwan. She used the method of this study was Experimental Research Design. The research consisted of two classes, VIII.A is the experiment class and VIII B is the control class. The instruments of this research are pre- test and post- test. She use T- test to analyze the data. The result of her study is jigsaw effective to improve students' ability in simple past tense.

Second research has written by Izah Fahrani. She has written a research, (2010) entitled "the effectiveness of Team Games Tournament (TGT) to teach reading viewed from students' self-Esteem". She conducted the study at seventh grade students of SMP Batik Surakarta in the academic year 2009/2010. Her research purpose are to find out whether (1) Team Games Tournament is more effective than the conventional method to teach reading, (2) students having high self-esteem have better reading skill than those having low self-esteem, and (3) there is no interaction effect between teaching methods and students' self-esteem on the students reading skill. This study used experimental research design. Her sample was taken by using cluster random sampling. She used the technique of collecting data were a non-test (a Questionnaire) and the test technique (Reading Test). The result of her study is Team Games Tournament (TGT) effective method to teach reading at the seventh grade students of SMP Batik Surakarta.

Third research has written by AgungSdayu (2014). He conducted about the effectiveness Team Games Tournament (TGT) technique in teaching reading of 
narrative text at the second grade students of SMPN 1 Pakuhaji in the academic year 2014/2015. His research is to find out whether Team Games Tournament (TGT) is effective in teaching reading of narrative text. The method in his study is experimental research design. The result of his research is effective in teaching reading of narrative text.

It is concluded that this research had similarities and differences with previous researcher. For the first, research stated that the researcher focused on using jigsaw technique to teach simple past tense. The similarities are about the used experimental research and so teach about past tense. For the second research the similarity side, both are applied the study at junior high school students, using Team Games Tournament (TGT) and using experimental research. In other hand, the differences between us are about the material, objective and place of the study and he taught reading. Similarity of the last researcher is the uses of Team games Tournament and the differences is he taught narrative text. The differences between threes study above are places, population, skills to conduct it. The researcher teach past tense by using Team Games Tournament (TGT) at MTS Roudhotul Khuffadz Aimas.

\section{Some Pertinent Ideas}

\section{Grammar}

Nordquist (2013:1) stated that grammar is a set of rules dealing with the syntax and word structures of the language, and it is usually intended as an aid to learning of that language. In grammar, there some topics about tense, then we used tense based on the occurrence time. According to Cambridge advanced learner's dictionary, grammar is rules about words change their form and combine with other words to make a sentences. Based on the explanation above the researcher conclude that grammar is important thing in teaching English, without grammar we cannot convey the meaning in our daily communications

\section{Tenses}

According to A.Faidla Rahman Ali (2007:246), Tense can be interpreted as a description or an explanation when the event that happen based on the time, such as: Now, Past, Future. Based on incident, tenses of English language can be apart become fourth kinds, it called "Four Fundamental Tense, are: present tense, past tense, future tense and past future tense. In this study the researcher will giving the explanation clearly about past tense. 


\section{Past tense}

There are some definition according to the experts that give an explanation about simple past tense. Based on Baehaqi (2009:35), past tense is describe something that happened the past. Past tense were used that told one happened or activities that happened in the past.Based on Eastwood (2012:59) the uses of simple past tense will be explained as follows:

Simple past tense is used when the action happened in past.

For example: I bought this coat yesterday.

I saw the film three weeks ago.

The time signals for past tense are: Yesterday, last, (week, year, day, month), ago, once and so on. In writing sentences, past tense was used because it appropriate with the curriculum in second semester for second grade students. The students were taught to write past tense on positive, negative and interrogative sentence form. Based on the explanation above the researcher concluded that past tense is used to describe or indicate an action that began in the past.

\section{Team Games Tournament (TGT)}

Teams-Games-Tournament, or TGT (Devries \& Slavin, 1978), combines within team cooperation with competition between teams and between individual representatives of different teams. According to Roy Killen (2007: 197), "TGT was Slavin "s original version of cooperative learning (Devries\&Slavin, 1978). It is similar to STAD in that teacheres present information to learners and then they have one another learn. The difference is the quizzes are replaced with tournaments in which learners compete with members of other teams in order to gain points for their home team." Teams Games Tournament (TGT) uses the samegeneral format as STAD (4 to 5 member groups $^{\text {ee }}$ studying work sheets). However, instead of individually administered quizzes at the end of study period, students play academic games to show their mastery of the topic studied. Whereas Slavin (2006: 338) explain that Teams Games Tournament or TGT, uses games that can be adapted to any subject. Game is better than individual games. They provide opportunities for his teammates to help each other or in other words work together so that the chance of winning will be great. If all students are put in teams of mixed ability, all have a good chance of success.

Based on the definition above, the researcher concludes that cooperative learning is a learning that divide the students into small groups. Each students must have the differentiation such as: Their gender, ability, races. It purpose to make balance each group.

The procedures of teaching past tense using Team Games Tournament in the class room are as follows: 
1. The teacher devides some group based on heterogeneous team and manage their seat, so that they can work collaborativelly.

2. The teacher give an explanation about past tense

3. The teacher gives worksheet containing about past tense questions.

4. The teacher suggest students to teach each other when one of them find difficulties in understanding the given material.

5. If there is a students questioning about the topic. The teacher suggest them first to ask in their team. If other students in team can not answer the question it mean that the teacher should be helped them to answer it.

6. The teacher walks around the class to check the students works.

7. The teacher as a source or facilitator if needed.

8. The teacher provides the number of card and the students should answer the question based on the number of card that they take before.

9. After finished on worksheets, the teacher ask them to participle in tournament. In this tournament, the students have to work individually to collect the score for their team and compete to do the worksheet in tournament table with other member from other team. After completing the tournament, they are assigned to check their works.

10. The teacher appreciates their work by giving rewards to the team for work in tournament.

\section{METHOD}

\section{Design and Sample}

The researcher used quasi experimental method. It was consist of two groups they are, experimental group and control group. To get the beginning data the researcher give pre- test to both of the classes (Experimental group and Control Group) at MTS Roudhotul Khuffadz Aimas. The purpose is to measure their understanding about past tense, after giving pre-test for the students then the researcher do treatment to both of the classes (Experimental group and Control Group) in the experimental group used Team Games Tournament (TGT) method and for the control group used conventional method. After giving the treatment, finallyy the researcher give post-test to both of the classes to know and compare theresult before and after giving treatment.

\section{Population and Sample of the Research}

The selection sample of population in this research are two classes, they are VIII.A and VIII.B. It is consist of 40 students, 28 male, and 12 female. The researcher choose VIII.A as control group and VIII.B as an Experimental group.In this research the researcher took a sample by using random sample, the researcher asked the students to count, before the researcher aksed them to count the researcher has 
devided based on the same ability with this way every students has same ability to be a sample.

\section{Result and Discussion}

In the data description, the researcher explains about the data that will be calculated on statistic pattern in this research. After the researcher was doing a pre test then giving treatment and doing post test, the researcher will get the needed data to prove her hyphotesis. The data in pre test and post test from both of two classes will be presented in the form of table. This table will be given the explanation about the data of pre test and post test that has done in this research.

The data which has collected in this research includes the result of test without Team Games Tournament (TGT) and used Team Games Tournament (TGT). The data from pre test and post test score both classes which are collected by the researcher are shown in the table below :

Table 4.1

The result of students score in Experimental group

\begin{tabular}{|c|c|c|c|}
\hline No & Name & Pre-Test & Post-Test \\
\hline 1. & $\overline{\mathrm{X} 1}$ & 67 & 80 \\
\hline 2 & $\mathrm{X} 2$ & 60 & 75 \\
\hline 3 & $\mathrm{X} 3$ & 70 & 86 \\
\hline 4 & $\mathrm{X} 4$ & 60 & 75 \\
\hline 5 & $\mathrm{X} 5$ & 65 & 78 \\
\hline 6 & $\mathrm{X} 6$ & 75 & 88 \\
\hline 7 & $\mathrm{X} 7$ & 65 & 85 \\
\hline 8 & $\mathrm{X} 8$ & 65 & 75 \\
\hline 9 & X9 & 55 & 72 \\
\hline 10 & $\mathrm{X} 10$ & 58 & 78 \\
\hline 11 & $\mathrm{X} 11$ & 55 & 74 \\
\hline 12 & $\mathrm{X} 12$ & 55 & 70 \\
\hline 13 & $\mathrm{X} 13$ & 63 & 82 \\
\hline 14 & $\mathrm{X} 14$ & 50 & 73 \\
\hline 15 & $\mathrm{X} 15$ & 55 & 70 \\
\hline 16 & $\mathrm{X} 16$ & 40 & 60 \\
\hline 17 & $\mathrm{X} 17$ & 52 & 78 \\
\hline 18 & $\mathrm{X} 18$ & 40 & 65 \\
\hline 19 & $\mathrm{X} 19$ & 55 & 74 \\
\hline \multirow[t]{4}{*}{20} & $\mathrm{X} 20$ & 50 & 70 \\
\hline & & 1115 & 1508 \\
\hline & & Average: & Average: \\
\hline & $\mathrm{N}: 20$ & $\begin{array}{r} \\
-\quad 55,75 \\
\end{array}$ & 75,4 \\
\hline
\end{tabular}




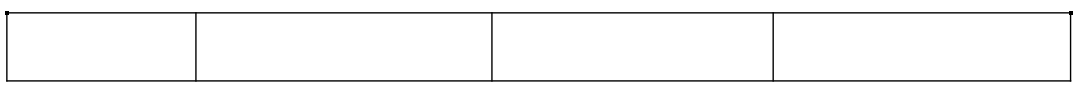

The table 4.1 showed that Experiment group improve significantly. It could be seen from mean score of pre-test 55,45 became 73,2 and post-test. The lowest score of pretest in Experimental group was 50 and the highest score was 75, after the experimental group has been giving Team Games Tournament Method (TGT) the lowest score was 63 of post test in Experimental group and the highest score was 88 .

Table 4.2

The reslt of students score in Control Class

\begin{tabular}{|c|c|c|c|}
\hline No & Name & Pre-Test & Post-Test \\
\hline 1. & Y1 & 60 & 73 \\
\hline 2 & Y2 & 70 & 81 \\
\hline 3 & Y3 & 65 & 75 \\
\hline 4 & Y4 & 65 & 72 \\
\hline 5 & Y5 & 65 & 78 \\
\hline 6 & Y6 & 70 & 75 \\
\hline 7 & Y7 & 60 & 74 \\
\hline 8 & Y8 & 65 & 75 \\
\hline 9 & Y9 & 50 & 74 \\
\hline 10 & Y10 & 40 & 65 \\
\hline 11 & Y11 & 43 & 67 \\
\hline 12 & Y12 & 50 & 65 \\
\hline 13 & Y13 & 55 & 68 \\
\hline 14 & Y14 & 45 & 60 \\
\hline 15 & Y15 & 50 & 68 \\
\hline 16 & Y16 & 40 & 68 \\
\hline 17 & Y17 & 56 & 73 \\
\hline 18 & Y18 & 45 & 63 \\
\hline 19 & Y19 & 55 & 67 \\
\hline 20 & Y20 & 65 & 70 \\
\hline & & 1114 & 1411 \\
\hline & & Average: & Average: \\
& N:20 & & $\mathbf{7 0 , 5 5}$ \\
& & & \\
\hline & & & \\
\hline
\end{tabular}

The table 4.2 it could be seen that the mean score of pre-test 52,9 and it became 68,2 on post-test. The lowest score of pre-test in Control group was 25 and the highest score was 70, and the lowest score of post test was 50 in Control group and the highest score was 78 .

Tabel 4.3

The Result of the calculation of test both of classes pretest Experimental group (VIII A) and control group 
at second grade of Mts Roudhotul Khuffadz.

\begin{tabular}{|c|c|c|c|c|c|c|}
\hline No & \multicolumn{2}{|c|}{ Pretest Experiment } & No & \multicolumn{2}{|c|}{ Pretest Control } & \\
\hline 1. & 67 & 4489 & 1. & 60 & 3600 & 216000 \\
\hline 2 & 60 & 3600 & 2 & 70 & 4900 & 343000 \\
\hline 3 & 70 & 4900 & 3 & 65 & 4225 & 274625 \\
\hline 4 & 60 & 3600 & 4 & 65 & 4225 & 274625 \\
\hline 5 & 65 & 4225 & 5 & 65 & 4225 & 274625 \\
\hline 6 & 75 & 5625 & 6 & 70 & 4900 & 343000 \\
\hline 7 & 65 & 4225 & 7 & 60 & 3600 & 216000 \\
\hline 8 & 65 & 4225 & 8 & 65 & 4225 & 274625 \\
\hline 9 & 55 & 3025 & 9 & 50 & 2500 & 125000 \\
\hline 10 & 58 & 3364 & 10 & 40 & 1600 & 64000 \\
\hline 11 & 55 & 3025 & 11 & 43 & 1849 & 79507 \\
\hline 12 & 55 & 3025 & 12 & 50 & 2500 & 125000 \\
\hline 13 & 63 & 3969 & 13 & 55 & 3025 & 166375 \\
\hline 14 & 50 & 2500 & 14 & 45 & 2025 & 91125 \\
\hline 15 & 55 & 3025 & 15 & 50 & 2500 & 125000 \\
\hline 16 & 40 & 1600 & 16 & 40 & 1600 & 64000 \\
\hline 17 & 52 & 2704 & 17 & 56 & 3136 & 175616 \\
\hline 18 & 40 & 1600 & 18 & 45 & 2025 & 91125 \\
\hline 19 & 55 & 3025 & 19 & 55 & 3025 & 166375 \\
\hline 20 & 50 & 2500 & 20 & 65 & 4225 & 274625 \\
\hline Total & 1155 & 68251 & Total & 1114 & 63910 & 3764248 \\
\hline Mean & $\mathbf{5 7 , 7 5}$ & - & Mean & 55,7 & - & - \\
\hline Min. & 40 & - & Min. & 40 & - & - \\
\hline Max. & 75 & - & Max & 70 & - & - \\
\hline
\end{tabular}

Based on the explanation above the researcher conclude that total score in experimental group was 1.155 and control group was 1.114. the mean score in experimental 57,75, minumum was 40 and maximum was 75 in control group got the mean score 55,7, Minimum was 40 and maximum 70.

Tabel 4.4

Result of calculation of postest both of classes Experimental group (VIII A 
) and control group

at second grade of Mts Roudhotul Khuffadz.

\begin{tabular}{|c|c|c|c|c|c|c|}
\hline No & \multicolumn{2}{|c|}{ Posttest Experiment } & No & \multicolumn{2}{|c|}{ Posttest Control } & \\
\hline 1. & 80 & 6400 & 1. & 73 & 5329 & 389017 \\
\hline 2 & 75 & 5625 & 2 & 81 & 6561 & 531441 \\
\hline 3 & 86 & 7396 & 3 & 75 & 5625 & 421875 \\
\hline 4 & 75 & 5625 & 4 & 72 & 5184 & 373248 \\
\hline 5 & 78 & 6084 & 5 & 78 & 6084 & 474552 \\
\hline 6 & 88 & 7744 & 6 & 75 & 5625 & 421875 \\
\hline 7 & 85 & 7225 & 7 & 74 & 5476 & 405224 \\
\hline 8 & 75 & 5625 & 8 & 75 & 5625 & 421875 \\
\hline 9 & 72 & 5184 & 9 & 74 & 5476 & 405224 \\
\hline 10 & 78 & 6084 & 10 & 65 & 4225 & 274625 \\
\hline 11 & 74 & 5476 & 11 & 67 & 4489 & 300763 \\
\hline 12 & 70 & 4900 & 12 & 65 & 4225 & 274625 \\
\hline 13 & 82 & 6724 & 13 & 68 & 4624 & 314432 \\
\hline 14 & 73 & 5329 & 14 & 60 & 3600 & 216000 \\
\hline 15 & 70 & 4900 & 15 & 68 & 4624 & 314432 \\
\hline 16 & 60 & 3600 & 16 & 68 & 4624 & 314432 \\
\hline 17 & 78 & 6084 & 17 & 73 & 5329 & 389017 \\
\hline 18 & 65 & 4225 & 18 & 63 & 3969 & 250047 \\
\hline 19 & 74 & 5476 & 19 & 67 & 4489 & 300763 \\
\hline 20 & 70 & 4900 & 20 & 70 & 4900 & 343000 \\
\hline Total & 1.508 & 114606 & Total & 1.411 & 100083 & 7136467 \\
\hline Mean & 75,4 & - & Mean & 70,55 & - & - \\
\hline Min. & 60 & - & Min. & 60 & - & - \\
\hline Max. & 88 & - & Max. & 81 & - & - \\
\hline
\end{tabular}

Based on the explanation above the researcher conclude that total score in experimental group was 1.508 and control group was 1.411. the mean score in experimental 75,4, minumum was 60 and maximum was 88 in control group got the mean score 70,55, Minimum was 60 and maximum was 81 . 
Table 4.5

Experimental Group

Clasifications of the score by Percent

\begin{tabular}{|c|c|c|c|c|}
\hline Clarification & N (Pre-test) & Percent & N (Post-Test) & Percent \\
\hline $0-25$ & 0 & $0 \%$ & 0 & $0 \%$ \\
\hline $26-50$ & 4 & $20 \%$ & 0 & $0 \%$ \\
\hline $51-75$ & 16 & $80 \%$ & 12 & $60 \%$ \\
\hline $76-100$ & 0 & $5 \%$ & 8 & $40 \%$ \\
\hline
\end{tabular}

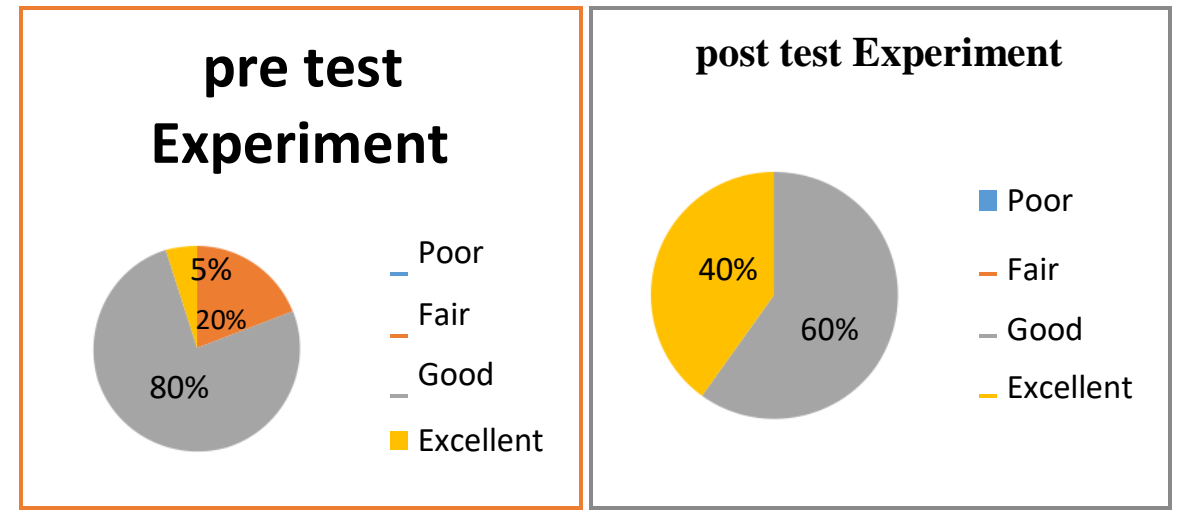

Based on students result the score of pre test and post test in experiemental group show that $60 \%$ students who good score, $40 \%$ students who got Excellent score and $20 \%$ students who got fair score in pre test of experimental group. in post test $80 \%$ students who got good score.

Table 4.6

Control Class

Clasifications of the score by Percent

\begin{tabular}{|c|c|c|c|c|}
\hline Clasification & N (Pre-test) & Percent & N (Post-Test) & Percent \\
\hline $0-25$ & 0 & $0 \%$ & 0 & $0 \%$ \\
\hline $26-50$ & 8 & $40 \%$ & 0 & $0 \%$ \\
\hline $51-75$ & 12 & $60 \%$ & 18 & $90 \%$ \\
\hline $76-100$ & 0 & $0 \%$ & 2 & $10 \%$ \\
\hline
\end{tabular}




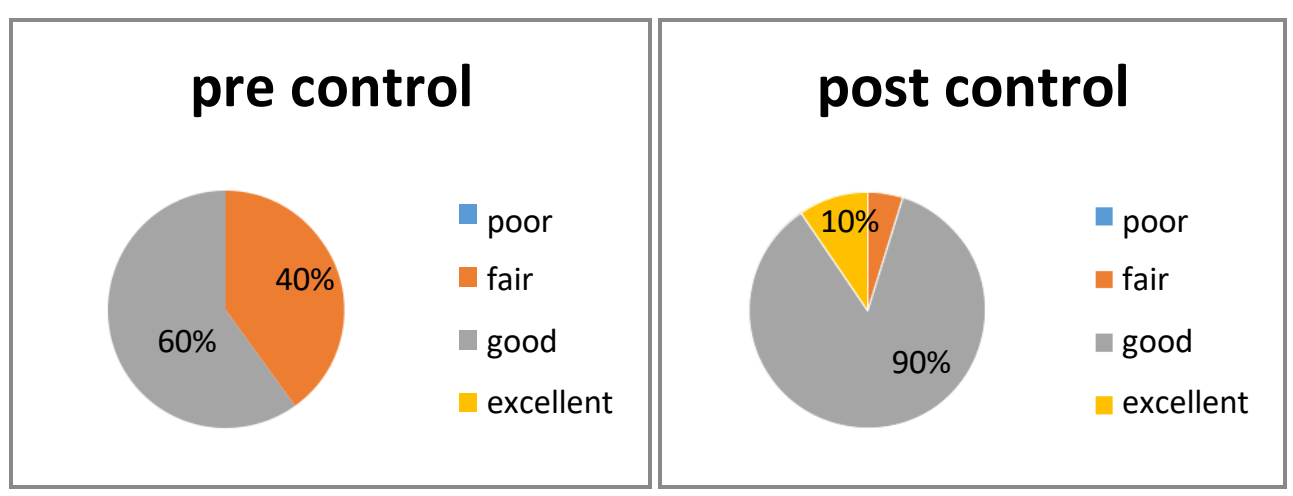

Based on students result the score of pre test and post test in control group show that $90 \%$ students who got good score, $10 \%$ students who got excellent score. and $40 \%$ students who got fair in pre test of control group $60 \%$ the student got good score.

\section{DISCUSSION}

This research has done at Mts Roudhotul Khuffadz. The researcher was doing her research about one month started from 13 mei until 10 june 2017. It was conducted in two classes they are : Experimental group and control group. The students of Experimental group were 20 students and for the control group were 20 students.

Before using Team Games Tournament (TGT), the researcher gave the pre-test to both classes (Experimental group and Control group). It aimed to measure students knowledge about past tense. The mean score of pre test in experimental group was 57,75 and control group was 55,7. From the data that has gotten by the researcher showed that both of classes got the lowest score than the researcher gave the treatment in Experimental group by using Team Games Tournament (TGT). In other side, control group also give the material by using conventional method. After giving the different methode than the researcher gave post-test score, the mean score in experimental group was 75,5 and control group was 70,55. It means that both classes got the significant score in experiment from 57,75 become 75,5 have difference 17,65 and control group from 55,7 become 70.55 have difference 14,85, it means that in experimental group has the significant score than in control group. It can proved from table 4.5 and 4.6 there are the different score that taught using TGT a conventional method. On that table, it showed the significant percentage of both two classes.

After getting the score, than the researcher can take conclusion that the hypothesis will be accepted or not. Finding on pre test and post test score are strenght by the result of comptation of T-test value. Here the researcher collected the data from getting score of Pre test and post test, (Varian of sample 2$)=28,261$. The researcher appeal and then got the result of $=2,407$. 


\section{and is refused if}

Based on the analyzed the researcher got the result, 2,407 2.021. so, was refused and was accepted and Team Games Tournament (TGT) Was effective in students understanding on past tense. The experimental group was observed directly by the researcher to know the progres in the program. The calculation shows that the experimental class is higher than control group. From the explanation above, the researcher conclude that the students who are taught by Team Games Tournament (TGT) have better result than the students who are taught without Team games

Tournament (TGT). It means that the researcher hypothesis was accepted.

\section{CONCLUSIONS}

As we knew past tense is important in our communicate to talked the accident that happened in the past like fairy tail, unforgettable moment and so on. In Junior high school has been studying about past tense although like that many students have the difficulties to understand and sometimes they confused to differencess the verb change that has in the sentence like Go became Went. In past tense we used Past Verb ( ) So, the researcher applied Team Games Tournament (TGT) in teaching Past tense to the students of Mts Roudhotul Khuffadz. It is significant and important role in achievement the goal and successfully in teaching english as the second languange. After conducting the research with the topic "The effectiveness of Team Games Tournament (TGT) in students understanding on past tense at the secon dgrade of Mts Roudhotul Khuffadz" the researcher expect that Team Games Tournament (TGT) can made the student esier in understanding past tense. Through Team Games Tournament, the students have good motivation and more powerfull in studying english. They felt happy, enjoy in teaching learning proccess and so can understand quickly. Beside that the students will be concentration and easier on the subject.

\section{References}

Ali, R. F. (2007). Fundamental of English Grammar. Yogyakarta:Pustaka Widyatama.

Sadya, A. (2014). The effectiveness of using Team Games Tournament (TGT) in teaching reading of Narrative Text. Jakarta: Universitas Hidayatullah Jakarta.

Farhani I. (2014). The effectiveness of Team Games Tournament (TGT) to teach reading viewed from students' Self- E steem. Surakarta: Universitas Sebelas Maret Surakarta.

Ridwan, F. S. (2014). The effectiveness of jigsaw Technique in teaching simple Past Tense. Jakarta: Universitas Hidayatullah Jakarta. 
Slavin, R. E. 2005. Cooperative Learning: Theory Research and Practice (2nd edition). Translater: Nurlita United States of America: Allyn and Bacon: A Simon \& Schuster Compani.

Slavin, R. E. 2009. Cooperative Learning: Teori, Riset, dan Praktik. Bandung:Nusa Media.

Sugiyono. 2007. Metode Penelitian Kuantitatif Kualitatif dan R\&D. Bandung: Alfabeta. 